\title{
Investigation into sleep and quality of life in patients with rheumatoid arthritis
}

\author{
Şebnem Çıınar Yücel ${ }^{1}$ \\ Yasemin Tokem ${ }^{2}$ \\ Esra Akın Korhan ${ }^{3}$ \\ Sultan Çalbay ${ }^{4}$
}

\begin{abstract}
Purpose: Aim of this study is to examine the relationship between the sleep and life of rheumatoid arthritis patients and the factors affecting this relationship.

Method and material: This research is a descriptive design study. This study was conducted in the Rheumatology polyclinic of a university hospital between January 2011 and June 2011 in Izmir/Turkey. Simple random sampling method was used in this study. The data of the research were collected through face-to-face interviews. "Patient Identification Form", "Pittsburg Sleep Quality Index" and "Nottingham Health Profile" scale were used for data collection.

Results: In Pittsburg Sleep Quality Index, total score average of the rheumatoid arthritis patients was found out to be $10.92 \pm 4.80$. Score averages of the sub-scales of Nottingham Health Profile were found as following: Pain= 67.48 \pm 26.53 , Energy Level=69.55 \pm 30.10 , Emotional Reaction= $50.78 \pm 27.00$, Physical Mobility $=50.59 \pm 24.40$, Social Isolation $=32.50 \pm 30.47$ and Sleep $=59.12 \pm$ 32.53 .
\end{abstract}

Conclusion: In line with the findings of the study, it was determined that a great majority of the rheumatoid arthritis patients had poor sleep quality and as well as a low quality of life.

Keywords: Rheumatoid arthritis; sleep quality; quality of life.

${ }^{1}$ Assist. Prof., Ege University, Faculty of Nursing, Fundamentals of Nursing Department, İzmir, Turkey; sebnem.cinar@ege.edu.tr

${ }^{2}$ Assoc. Prof., Izmir Katip Çelebi University, Faculty of Health Science-Department of Nursing, Nursing Department of Internal Medicine, Izmir, Turkey; yasemin.tokem@ikc.edu.tr

${ }^{3}$ Assist. Prof., Izmir Katip Çelebi University, Fundamentals of Nursing Department, İzmir, Turkey; akinesra80@hotmail.com

${ }^{4} \mathrm{RN}$, İstanbul University, Cerrahpaşa Medicine Faculty, İstanbul, Turkey; sultan calbay@hotmail.com 
Çınar Yücel, S.., Tokem, Y., Korhan, E. A., \& Çalbay, S. (2014). Investigation into sleep and quality of life in patients with rheumatoid arthritis. International Journal of Human Sciences, 11(1), 457-468. doi: 10.14687/ijhs.v11i1.2706

\section{Introduction}

Rheumatoid arthritis (RA) is a chronic and systemic autoimmune disease which lacks a completely known etiology, principally attacks the synovial joints, can be seen in all the races and etnic groups, is accompanied by frequent inflammations and can lead to serious deformities and impairments through joint involvement accompanied by frequent inflammations (Cakırbay et al., 2004; Solak et al., 2009; Kiper \& Sunal, 2009). It was reported that annual prevalence of RA which is one of the most common inflammatory diseases was $0.5 \%-1 \%$ in all the societies while its incidence rate was found out to vary between 0.2-0.4 per 1000 individuals (Kiper \& Sunal, 2009). $\mathrm{RA}$ is seen in women 3 times more frequently than men and it is mostly observed in the age group of 30-50. Several members of the same family can develop RA and having a first degree relative with rheumatoid arthritis increases the incidence risk by 16 times (Inan, 2009).

Rheumatoid artritis (RA) has important impacts on the physical and psychosocial health and affects the quality of life negatively (Günaydın et al., 2009). Impacts of the disease can be observed in all parts of the life including family life, social relations and business life. (Altan et al., 2004). RA symptoms increase more specifically at times of inflammation (Drewes, 1999). About 30 $\%$ of all the patients becomes unfunctional and dependent on other people at the 10th year of the appearance of RA (Kiper \& Sunal, 2009). In RA, the most common complaints of the patients include joint pain, swelling in the joints, morning stiffness, fatigue, hopelesness, pain, lack of energy and sleep disorders. Such systemic symptoms as weakness, quick exhaustion, loss of appetite and weight loss are encountered in many patients (Drewes, 1999; Bourguignon et al., 2003; Cakırbay et al., 2004; İnan, 2009).

$\mathrm{RA}$ is one of the diseases in which sleep disorders are commonly encountered. In some studies, it was expressed that more than half of the patients with RA experienced sleep disorders (Moldofsky et al., 1995; Cakırbay et al., 2004). However, some studies revealed that frequency of sleep disorders of the patients varied between $54 \%$ and $70 \%$ (Dewres, 1999; Moldofsky et al., 1983). It is widely thought that physiological and psychosocial problems cause sleep disorders in patients with RA. It is known that RA patients suffering from sleep disorders have more problems in their daily lives, their quality of life reduces and thus, they become more inclined to seek for help. It was detected that sleep disorders reported as an important problem by the patients were associated with pain, number of the sensitive joints, fatigue and depression (Bourguignon et al., 2003). Difficulty of falling asleep, daytime sleepiness, inability of falling asleep, increase in the frequency of waking at night, being sleepy during the day and poor sleep quality were detected as the most frequently observed sleep disorders (Moldofsky et al., 1983; Lavie et al., 1992; Drewes et al., 1998). In the studies concerning sleep in RA patients, it was observed that the interruptions 
Çınar Yücel, Ş., Tokem, Y., Korhan, E. A., \& Çalbay, S. (2014). Investigation into sleep and quality of life in patients with rheumatoid arthritis. International Journal of Human Sciences, 11(1), 457-468. doi: 10.14687/ijhs.v11i1.2706

during the sleep pose a bigger problem than the changes in the sleep stages. RA patients get difficulty in falling asleep, wake several times during the night and early in the morning and thus, feel sleepy during the day (Hirsch et al., 1994; Lavie et al., 1992; Moldofsky et al.,1995; Drewes et al., 1999). When the literature was examined, it was seen that there was only a limited number of studies concerning the qualities of life and sleep among RA patients. Moreover, there is also a few studies where PSQI questionnaire was used to assess the sleep quality (Cakirbay et al., 2004). Literature supports that sleep disorders affect the quality of life negatively in RA patients. It is thought that this research will raise awareness as it is important to address the sleep disorders of RA patients and their negatively affected quality of life perceptions and will shed light on the other researches to be conducted in this respect.

\section{Purpose}

Objective of this descriptive study is to examine the relationship between sleep quality and quality of life in RA patients as well as the factors affecting this relationship.

\section{Method and material}

\section{The place and time of the study}

This study was conducted in the Rheumatology polyclinic of a university hospital between January 2011 and June 2011 in İmir/Turkey.

\section{Population and sample selection}

Simple random sampling method was used in this study. Study population consisted of all the patients, who were being followed up by the Rheumatology polyclinic, were diagnosed with RA and were aged 18 and above $(\mathrm{N}=400)$ while research sample was composed of $80(20 \%)$ patients who complied with the research limitations and accepted to participate in the study.

\section{Type of study}

This study used a descriptive design.

\section{The variables}

The variables were age, sex, marital status, education status, PSQI, Nottingham Health Profile.

\section{Data collection}

\section{Data collection method}

The data of the research were collected through face-to-face interviews. 
Çınar Yücel, S.., Tokem, Y., Korhan, E. A., \& Çalbay, S. (2014). Investigation into sleep and quality of life in patients with rheumatoid arthritis. International Journal of Human Sciences, 11(1), 457-468. doi: 10.14687/ijhs.v11i1.2706

\section{Data collection tools}

Data were collected by using the "Patient Identification Form" regarding the demographic features of RA patients and the disease-related information, "Pittsburg Sleep Quality Index (PSQI)" to measure the sleep quality and "Nottingham Health Profile" to measure the quality of life of the patients.

Patient identification form contained information about age, sex, marital status, education status and napping. Patient identification form was designed by the researchers.

PSQI which was developed by Buysse et al. (1989) and was tested for its reliability and validity in Turkey by Agargün et al. (1996) is a self-report scale assessing the sleep quality and related disorders in the last month. PSQI has 7 components: subjective sleep quality (component 1), sleep latency (component 2), sleep duration (component 3), habitual sleep activity (component 4), sleep disorder (component 5), use of sleeping pills (component 6) and daytime dysfunction (component 7). Total score obtained from these components corresponds to the total PSQI score. Answer of each question is scored between 0 and 3 depending on the frequency of the symptom. If it never occurred, this score is 0 ; if its frequecy is less than one in a week, the score is 1 ; if its frequency is one or two in a week, the score is 2; if its frequency is three or more in a week, the score is 3 . In the assessment of the sleep in the scale, very good is 0 ; rather good is 1 ; rather bad is 2 and very bad is 3 . Total score varies between 0 and 21 . High values indicate that sleep quality is bad and the level of sleep disorder is high. A total score more than 5 clinically shows that the sleep quality is signicantly bad.

Adaptation of Nottingham Health Profile into Turkish and evaluation of its psychometric properties were conducted by Kücükdeveci et al. (2000). Consisting of 38 items, the scale was composed of six sub-scales which evaluated the physical mobility, energy, pain, social isolation, sleep and emotional reactions. Total score of the scale and the scores of its sub-scales vary between 0 and 100. Increase in the score of the scale indicates a reduction in the quality of life. As there is not a cut point in the assessment of the scale, group is evaluated within itself and thus, low scores are interpreted as less influence and high scores are interpreted as more influence. In the assessment of the scale, increase in the score of life quality means a bad quality of life while decrease in the scores means a good quality of life.

\section{Limitations of the study}

The results of this study are limited, with Rheumatology polyclinic of a university hospital in a single institution. 
Çınar Yücel, Ş., Tokem, Y., Korhan, E. A., \& Çalbay, S. (2014). Investigation into sleep and quality of life in patients with rheumatoid arthritis. International Journal of Human Sciences, 11(1), 457-468. doi: 10.14687/ijhs.v11i1.2706

\section{Research ethics}

Written permissions were taken from the Scientific Ethics Committee of the Nursing School to implement this research and from the university hospital to conduct it. Besides, verbal approval was taken from each patients participating in the research. Participation in this study was voluntary.

\section{Evaluation of data}

Analysis of the research data was performed by using the number, percentage, arithmetic mean, Kruskal Wallis, MannWhitney U, significance test of difference between two means and Pearson correlation analysis in the SPSS 15.0 package program. (SPSS, 2006).

\section{Results}

\section{Demographic Features}

According to the findings of this study conducted to examine the sleep status and quality of life in RA patients, $58.8 \%$ of the RA patients were at the age group of 40-59, their age average was $47.27 \pm 12.49(\min 20, \max 79), 62.5 \%$ of them were female and $67.5 \%$ of them were married (Table 1).

\begin{tabular}{|c|c|c|c|c|}
\hline \multicolumn{5}{|c|}{$\begin{array}{l}\text { Table 1: Distribution of the General Characteristics of the RA Patients According to the } \\
\text { PSQI Total Score Means }\end{array}$} \\
\hline \multicolumn{2}{|c|}{ General Characteristics $(n=80)$} & $\mathbf{N}$ & Percent & PSQI Total Score Means X \pm SS \\
\hline Age & $\begin{array}{l}20-39 \\
40-59 \\
60-79 \\
\end{array}$ & $\begin{array}{l}22 \\
47 \\
11 \\
\end{array}$ & $\begin{array}{l}27.5 \\
58.8 \\
13.7 \\
\end{array}$ & $\begin{array}{l}10.5 \pm 4.55 \\
10.4 \pm 4.45 \\
13.6 \pm 6.18\end{array}$ \\
\hline \multicolumn{5}{|c|}{$* \mathrm{KW}=3.34, \mathrm{p}=0.18$} \\
\hline Sex & $\begin{array}{l}\text { Female } \\
\text { Male }\end{array}$ & $\begin{array}{l}50 \\
30\end{array}$ & $\begin{array}{l}62.5 \\
37.5 \\
\end{array}$ & $\begin{array}{l}11.1 \pm 4.93 \\
10.6 \pm 4.63\end{array}$ \\
\hline \multicolumn{5}{|l|}{$* *_{\mathrm{t}}=0.43, \mathrm{p}=0.66$} \\
\hline Marital status & $\begin{array}{l}\text { Married } \\
\text { Single } \\
\text { Divorced }\end{array}$ & $\begin{array}{l}54 \\
9 \\
17 \\
\end{array}$ & $\begin{array}{l}67.5 \\
11.2 \\
21.3 \\
\end{array}$ & $\begin{array}{l}10.2 \pm 4.85 \\
13.4 \pm 4.12 \\
11.6 \pm 4.66\end{array}$ \\
\hline \multicolumn{5}{|c|}{$* \mathrm{KW}=3.91, \mathrm{p}=0.14$} \\
\hline Education level & $\begin{array}{l}\text { Primary } \\
\text { Secondary } \\
\text { High school } \\
\text { University and } \\
\text { higher }\end{array}$ & $\begin{array}{l}18 \\
22 \\
24 \\
16\end{array}$ & $\begin{array}{l}22.5 \\
27.5 \\
30 \\
20\end{array}$ & $\begin{array}{l}14.0 \pm 5.26 \\
10.3 \pm 4.12 \\
9.50 \pm 4.47 \\
10.4 \pm 4.50\end{array}$ \\
\hline \multicolumn{5}{|c|}{$* \mathrm{KW}=8.81, \mathrm{p}=0.03$} \\
\hline Napping & $\begin{array}{l}\text { Yes } \\
\text { No }\end{array}$ & $\begin{array}{l}36 \\
44 \\
\end{array}$ & $\begin{array}{l}45 \\
55 \\
\end{array}$ & $\begin{array}{l}13.02 \pm 4.19 \\
9.22 \pm 4.62\end{array}$ \\
\hline$* *_{\mathrm{t}}=3.81, \mathrm{p}=0.00$ & & & & \\
\hline
\end{tabular}

It was determined that PSQI sleep qualities of RA patients at the age group of 60-79 (PSQI=13.6 \pm 6.18 ) were worse than the patients of the other age groups but the difference between them was not statistically significant $(\mathrm{p}>0.05)$. While PSQI total score average of the 
Çınar Yücel, Ş., Tokem, Y., Korhan, E. A., \& Çalbay, S. (2014). Investigation into sleep and quality of life in patients with rheumatoid arthritis. International Journal of Human Sciences, 11(1), 457-468. doi: 10.14687/ijhs.v11i1.2706

female patients was $11.1 \pm 4.93$, that of male patients was $10.6 \pm 4.63$ but this difference was not found statistically significant $(\mathrm{p}>0.05)$. It was stated that sleep qualities of single patients (PSQI=13.4 \pm 4.12 ) were worse when compared to the married and divorced patients but it was not also statistically significant $(\mathrm{p}>0.05)$. It was also observed that RA patients (PSQI $=14.0 \pm 5.26)$ graduating from the primary school had worse sleep qualities and there was a statistically significant difference between the PSQI total score averages by the education status $(\mathrm{p}<0.05)$. Besides, it was found out that PSQI total score average of RA patients who took naps was $13.02 \pm 4.19$ and a significant difference was found between napping status and PSQI total score average $(p<0.05)$ (Table 1).

It was determined that most of the patients $(88.8 \%$ ) had poor sleep qualities (Global PSQI Score > 5). PSQI Total Score Average of RA patients was found out to be $10.92 \pm 4.80$ ( $\mathrm{min}=3$, $\max =21)$. When score averages of the PSQI subcomponents were examined, the following score averages were detected: $1.83 \pm 0.77$ for the Component 1 (Subjective Sleep Quality); $2.00 \pm 0.94$ for the Component 2 (Sleep Latency); $1.23 \pm 1.00$ for the Component 3 (Sleep Duration); $1.35 \pm 1.22$ for the Component 4 (Habitual Sleep Activity); $1.75 \pm 0.72$ for the Component 5 (Sleep Disorder); $1.07 \pm 1.19$ for the Component 6 (Use of Sleeping Pills) and 1.68 \pm 0.80 for the Component 7 (Daytime Dysfunction) (Table 2).

\begin{tabular}{l}
\hline Table 2: Distribution of the PSQI Total Score Averages of the RA Patients \\
\begin{tabular}{|l|l|}
\hline PSQI subcomponents & Mean \\
\hline Global Sleep & $10.92 \pm 4.80$ \\
\hline Subjective Sleep Quality & $1.83 \pm 0.77$ \\
\hline Sleep Latency & $2.0 \pm 0.94$ \\
\hline Sleep Duration & $1.23 \pm 1.0$ \\
\hline Habitual Sleep Activity & $1.35 \pm 1.22$ \\
\hline Sleep Disorder & $1.75 \pm 0.72$ \\
\hline Use of Sleeping Bills & $1.07 \pm 1.19$ \\
\hline Daytime Dysfunction & $1.68 \pm 0.80$ \\
\hline
\end{tabular}
\end{tabular}

Score averages of the sub-scales of Nottingham Health Profile were found as following: pain $=67.48 \pm 26.53$, Energy Level=69.55 \pm 30.10 , Emotional Reaction= 50.78 \pm 27.00 ; Physical Mobility $=50.59 \pm 24.40$, Social Isolation $=32.50 \pm 30.47$ and Sleep $=59.12 \pm 32.53$ (Table 3).

\begin{tabular}{|l|l|l|}
\hline Table 3. Distribution of the Score Averages on the Sub-Scales of Nottingham Health Profile \\
\hline $\begin{array}{l}\text { Nottingham Health Profile Sub- } \\
\text { Scales } \\
(\mathbf{n = 8 0 )}\end{array}$ & Nottingham Health Profile Score Averages \\
\cline { 2 - 3 } & $\mathbf{X}$ & SD \\
\hline Pain & 67.48 & 26.53 \\
\hline Energy Level & 69.55 & 30.10 \\
\hline Emotional Reaction & 50.78 & 27.00 \\
\hline Physical Mobility & 50.59 & 24.40 \\
\hline Social Isolation & 32.50 & 30.47 \\
\hline Sleep & 59.12 & 32.53 \\
\hline
\end{tabular}


Çınar Yücel, Ş., Tokem, Y., Korhan, E. A., \& Çalbay, S. (2014). Investigation into sleep and quality of life in patients with rheumatoid arthritis. International Journal of Human Sciences, 11(1), 457-468. doi: 10.14687/ijhs.v11i1.2706

It was determined that there was not a statistically significant difference between the score averages of RA patients in the Pain, Energy Level, Physical Mobility and Sleep sub-scales of Nottingham Health Profile by the variables of age, gender, marital status and education status $(\mathrm{p}>0.05)$ (Table 4). Although there was a statistically significant difference between the marital statuses of RA patients and their score averages in the sub-scales of Emotional Reaction and Social Isolation, an equality was detected at the level of significance $(p=0.05)$ (Table 4).

\begin{tabular}{|c|c|c|c|c|c|c|}
\hline \multicolumn{7}{|c|}{$\begin{array}{l}\text { Table 4. Distribution of the Score Averages on the Sub-Scales of Nottinghan Health Profile } \\
\text { According to the Personal Information of RA Patients }\end{array}$} \\
\hline \multirow{3}{*}{$\begin{array}{l}\text { Demographic } \\
\text { Characteristics }\end{array}$} & \multicolumn{6}{|c|}{ Nothingham Health Profile Sub-Scales } \\
\hline & Pain & $\begin{array}{l}\text { Energy } \\
\text { Level }\end{array}$ & $\begin{array}{l}\text { Emotional } \\
\text { Reaction }\end{array}$ & $\begin{array}{l}\text { Physical } \\
\text { Mobility }\end{array}$ & $\begin{array}{l}\text { Social } \\
\text { Isolation }\end{array}$ & Sleep \\
\hline & $\mathrm{X} \pm \mathrm{SS}$ & $\mathrm{X} \pm \mathrm{SS}$ & $\mathrm{X} \pm \mathrm{SS}$ & $\mathrm{X} \pm \mathrm{SS}$ & $\mathrm{X} \pm \mathrm{SS}$ & $\mathrm{X} \pm \mathrm{SS}$ \\
\hline \multicolumn{7}{|l|}{ Age $(n=80)$} \\
\hline $20-39(n=22)$ & $68.16 \pm 26.10$ & $71.18 \pm 29.64$ & $50.45 \pm 30.20$ & $52.27 \pm 29.54$ & $33.63 \pm 31.09$ & $55.45 \pm 34.87$ \\
\hline $40-59(n=47)$ & $64.18 \pm 27.29$ & $66.63 \pm 30.30$ & $47.94 \pm 25.79$ & $45.95 \pm 20.95$ & $27.23 \pm 26.28$ & $56.38 \pm 30.46$ \\
\hline \multirow[t]{2}{*}{$60-79(n=11)$} & $80.22 \pm 21.80$ & $78.77 \pm 30.83$ & $63.57 \pm 23.85$ & $67.04 \pm 21.11$ & $52.72 \pm 39.26$ & $78.18 \pm 32.80$ \\
\hline & $\begin{array}{l}\mathrm{KW}=295 \\
\mathrm{p}=0.22\end{array}$ & $\begin{array}{l}\mathrm{KW}=1.74 \\
\mathrm{p}=0.41\end{array}$ & $\begin{array}{l}\mathrm{KW}=2.96 \\
\mathrm{p}=0.22\end{array}$ & $\begin{array}{l}\mathrm{KW}=6.73 \\
\mathrm{p}=0.22\end{array}$ & $\begin{array}{l}\mathrm{KW}=4.24 \\
\mathrm{p}=0.12\end{array}$ & $\begin{array}{l}\mathrm{KW}=4.83 \\
\mathrm{p}=0.08\end{array}$ \\
\hline \multirow{4}{*}{$\begin{array}{l}\text { Sex }(n=80) \\
\text { Female }(n=50) \\
\text { Male }(n=30)\end{array}$} & & & & & & \\
\hline & $66.39 \pm 26.83$ & $68.86 \pm 30.25$ & $50.39 \pm 27.85$ & $49.58 \pm 24.88$ & $29.33 \pm 28.63$ & $56.60 \pm 34.61$ \\
\hline & $69.30 \pm 26.38$ & $69.97 \pm 30.31$ & $51.43 \pm 25.98$ & $51.20 \pm 24.34$ & $34.40 \pm 31.64$ & $63.33 \pm 28.80$ \\
\hline & $\begin{array}{l}\mathrm{t}=-0.47 \\
\mathrm{p}=0.63\end{array}$ & $\begin{array}{l}\mathrm{t}=0.15 \\
\mathrm{p}=0.87\end{array}$ & $\begin{array}{l}\mathrm{t}=-0.16 \\
\mathrm{p}=0.87\end{array}$ & $\begin{array}{l}\mathrm{t}=0.28 \\
\mathrm{p}=0.77\end{array}$ & $\begin{array}{l}\mathrm{t}=0.71 \\
\mathrm{p}=0.47\end{array}$ & $\begin{array}{l}\mathrm{t}=-0.89 \\
\mathrm{p}=0.37\end{array}$ \\
\hline \multicolumn{7}{|l|}{ Marital Status } \\
\hline Married $(n=54)$ & $63.17 \pm 26.13$ & $66.01 \pm 31.39$ & $45.63 \pm 26.37$ & $48.14 \pm 22.17$ & $36.38 \pm 28.75$ & $56.29 \pm 33.21$ \\
\hline Single $(n=9)$ & $77.77 \pm 26.35$ & $81.46 \pm 29.41$ & $64.13 \pm 24.68$ & $69.45 \pm 26.59$ & $44.44 \pm 35.74$ & $71.11 \pm 31.79$ \\
\hline \multirow{2}{*}{$\begin{array}{l}\text { Widow/Divorced } \\
(n=17)\end{array}$} & $75.73 \pm 25.94$ & $74.47 \pm 25.10$ & $60.08 \pm 26.66$ & $48.38 \pm 27.05$ & $45.58 \pm 28.60$ & $61.76 \pm 30.86$ \\
\hline & $\begin{array}{l}\mathrm{KW}=4.56 \\
\mathrm{p}=0.10\end{array}$ & $\begin{array}{l}\mathrm{KW}=2.54 \\
\mathrm{p}=0.28\end{array}$ & $\begin{array}{l}\mathrm{KW}=5.85 \\
\mathrm{p}=0.05\end{array}$ & $\begin{array}{l}\mathrm{KW}=5.63 \\
\mathrm{p}=0.06\end{array}$ & $\begin{array}{l}\mathrm{KW}=7.85 \\
\mathrm{p}=0.05\end{array}$ & $\begin{array}{l}K W=1.63 \\
p=0.44\end{array}$ \\
\hline \multirow{6}{*}{$\begin{array}{l}\text { Education } \\
\text { Status }(n=80) \\
\text { Primary }(n=18) \\
\text { Secondary }(n=22) \\
\text { High school }(n=24) \\
\text { University and } \\
\text { higher }(n=16)\end{array}$} & & & & & & \\
\hline & $80.27 \pm 23.11$ & $81.45 \pm 23.51$ & $61.05 \pm 21.95$ & $59.02 \pm 23.79$ & $46.66 \pm 38.80$ & $68.88 \pm 36.44$ \\
\hline & $68.93 \pm 26.90$ & $69.66 \pm 30.71$ & $55.00 \pm 29.17$ & $54.54 \pm 24.25$ & $32.50 \pm 29.59$ & $57.72 \pm 33.79$ \\
\hline & $61.45 \pm 29.23$ & $62.46 \pm 31.57$ & $45.78 \pm 24.34$ & $43.64 \pm 24.31$ & $26.87 \pm 21.76$ & $60.00 \pm 27.66$ \\
\hline & $60.13 \pm 21.53$ & $66.63 \pm 32.21$ & $40.93 \pm 29.98$ & $46.09 \pm 23.59$ & $25.00 \pm 29.66$ & $48.75 \pm 32.63$ \\
\hline & $\begin{array}{l}\mathrm{KW}=7.0 \\
\mathrm{p}=0.07\end{array}$ & $\begin{array}{l}\mathrm{KW}=4.1 \\
\mathrm{p}=0.25\end{array}$ & $\begin{array}{l}\mathrm{KW}=6.5 \\
\mathrm{p}=0.08\end{array}$ & $\begin{array}{l}\mathrm{KW}=5.6 \\
\mathrm{p}=0.12\end{array}$ & $\begin{array}{l}\mathrm{KW}=4.1 \\
\mathrm{p}=0.24\end{array}$ & $\begin{array}{l}\mathrm{KW}=3.5 \\
\mathrm{p}=0.31\end{array}$ \\
\hline
\end{tabular}


Çınar Yücel, S.., Tokem, Y., Korhan, E. A., \& Çalbay, S. (2014). Investigation into sleep and quality of life in patients with rheumatoid arthritis. International Journal of Human Sciences, 11(1), 457-468. doi: 10.14687/ijhs.v11i1.2706

\section{Discussion}

\section{Sleep Problems}

In patients with RA, sleep problems are as common as other symptoms of the disease (pain, fatique, movement restriction etc.) and most of these symptoms even cause increases in the sleep problems. In many studies, it was reported that the rate of sleep problems observed in patients with RA was as high as 50-75\%. Out of these studies, those examining the sleep disorder through PSQI revealed that total score averages varied between 5.76 and 10.42 (Cakirbay, 2004; Kiper ve Sunal, 2009; Luyster et al., 2011; Nicassio and Wallston, 1992). We also obtained similar findings in our study (10.92) and determined that $88.8 \%$ of all the participants had a poor quality of sleep.

When PSQI sub-components of RA patients were examined, it was determined that the Sleep Latency (Component 2) score average of the patients was higher than the other components. Sleep latency is an expression used to explain that patient gets difficulty in falling asleep in the bed and remains awake despite lying in the bed. This situation can be provoked by the conditions of the living environment of the patient or changes in the environment as well as pain resulting from the disease and inappropriate positioning. Likewise, it was reported in many researches that RA patients had difficulties in falling asleep (Hirsch et al., 1994; Lavie et al., 1992; Solak et al., 2009; Kiper \& Sunal, 2009). In our study, Sleep Duration (Component 3), Habitual Sleep Activity (Component 4) and Sleep Disorder (Component 5) sub-components were determined to be at bad level. It is thought that these results show that patients can not sleep sufficiently and have sleep problems and RA-related symptoms may have contributed to the deterioration of this situation. In many studies where functional failure and severe pain were reported to affect the sleep quality negatively at a significant level, it was stated that duration of the disease, comorbid conditions were the other reasons increasing the sleep disorders as well as age, sex, low income level and the use of some drugs (steroid, anti-TNF etc.) (Kaya, 2007; Luyster et al., 2011; Nicassio et al., 2012; Kiper \& Sunal, 2009). Despite the fact that a statistically significant difference was not found when the interaction between the demographic characteristics of the patients (age, gender, marital status and education level) and their qualities of sleep was examined, it was determined that the qualities of sleep were worse in the RA patients who aged 60 and over, were female, single and graduates of primary school when compared to the other groups. Intensification of symptoms depending on the lengthening of the disease duration with age (ex: increase in the pain) can be attributed to the development of deformities, comorbid diseases, depression as well as the loss of social support. Beside to the symptoms of the disease, RA patients also have to maintain their daily individual and familial responsibilities. It is thought that heavy responsibilities of women in the house concerning children and husband as especially required by the social norms in our country, their obligation to 
Çınar Yücel, Ş., Tokem, Y., Korhan, E. A., \& Çalbay, S. (2014). Investigation into sleep and quality of life in patients with rheumatoid arthritis. International Journal of Human Sciences, 11(1), 457-468. doi: 10.14687/ijhs.v11i1.2706

maintain their traditional roles within the family and their anxiety resulting from problems experienced in the house due to disease symptoms may also be of crucial importance. As a matter of fact, most of the abovementioned factors are expressed as the general reasons of higher incidence of sleep problems in women in the other disease groups and general population. Thus, it can be an appropriate practice to reduce the anxiety levels of RA patients by providing psychological support. In spite of these problems experienced by married women, a surprising result of our study was that sleep qualities of single patients were worse than the married and divorced women. It is thought that their sleep qualities may be lower due to such factors as disbelief towards future, loneliness, assuming responsibilities alone and stress.

It was determined in our study that almost half of the RA patients (45\%) took naps and their sleep qualities were worse than those who did not take naps. Under normal circumstances, taking a nap is beneficial as it helps increase the brain power of the individual, is good for mental health and reduces the death risk resulting from many chronic diseases. However, the time of this nap is of great importance. It provides the abovementioned benefits on condition that it is taken at noontime and does not exceed 60 minutes. Therefore, the finding of this research can be attributed to the fact that taking naps at inappropriate hours of the day (ex: close to the evening) and a duration of napping more than 60-90 minutes (after 90 minutes, the person enters into a new sleep cycle and thus the quality of night sleep can be affected) deteriorate the quality of night sleep, make it difficult to fall asleep and impede a sufficient amount of sleep.

\section{Quality of Life}

In patients with RA, the quality of life is an important parameter that needs to be measured periodically both to assess impacts of the disease and the applied treatment and to determine the appropriate treatment method when needed (Kaya, 2007). Although the quality of life is measured by various tools, it is reported in the studies where the disease-specific quality of life scales are used that the qualities of life of RA patients are affected at different dimensions and levels. In a study regarding the quality of life perception in RA patients, it was determined that patients experienced anxiety in their social relations due to their disabilities (Nunez, 2006). In another study, the quality of life was reported to be poor in relation to the physical restriction (Borman, 2007). Our study revealed that the most negatively affected dimension was the social isolation dimension for the participants. This is a striking result as it shows the importance of social support for the patients with RA. There are also other studies which indicate that social support is greatly important for the physical restriction and increase in this support reduces the physical restriction to the same extent (Pollard et al., 2005). 
Çınar Yücel, S.., Tokem, Y., Korhan, E. A., \& Çalbay, S. (2014). Investigation into sleep and quality of life in patients with rheumatoid arthritis. International Journal of Human Sciences, 11(1), 457-468. doi: 10.14687/ijhs.v11i1.2706

When the relationship between the quality of life and the demographic features was examined in RA patients, it was determined that the quality of life scores of participants at the age group of 60-70, of male patients, of single patients/widows and of those having the lowest education levels (graduates of primary school) were lower when compared to the other groups but this difference was not statistically different. In the literature, there exist many studies which examine the impacts of demographic features on the quality of life and the reported results differ from one another. For instance, it is reported that physical quality of life of aged RA patients is affected negatively by the increase in the duration of the disease (Aktekin et al., 2008), female participants have worse qualities of life, there is a significant relationship between marital status and social isolation (Nunez et al., 2006) and education levels do not affect the subdimensions of the quality of life (Akyol, 1993). No matter what the deterministic factors are, it is thought that intensity of the disease symptoms and perception of the patient concerning them significantly determine the quality of life in RA patients. Relationship between sleep disorders and quality of life

In our study, a moderate positive relationship was found between PSQI and "Pain" sub-scale of the NHP (Nottingham Health Profile); a weak positive relationship was found between PSQI and the Energy Level, Emotional Reaction and Physical Mobility; a too weak positive relationship was found between PSQI and the Social Isolation; and a high positive relationship was detected between PSQI and sleep. Many studies frequently reveal that pain and quality of life are highly associated in RA patients. It is a highly expected result that, pain which is the most important indicator of the quality of life, is the symptom that has the most negative impact on sleep quality as well as being the most common symptom experienced by RA patients.

\section{Conclusion and recommendations}

In line with the findings of the study, it was determined that sleep quality of a great majority of the RA patients was poor and their quality of life levels were low. Poor sleep qualities of RA patients were principally associated with pain, fatigue and the physical restriction. Sleep disorders experienced due to these factors make patients perceive their qualities of life negatively. Nurses assume important responsibilities to manage these factors through pharmacological and behavioral interventions and to enable RA patients to lead a normal life as much as possible. 
Çınar Yücel, Ș., Tokem, Y., Korhan, E. A., \& Çalbay, S. (2014). Investigation into sleep and quality of life in patients with rheumatoid arthritis. International Journal of Human Sciences, 11(1), 457-468. doi: 10.14687/ijhs.v11i1.2706

\section{References}

Altan L., Bingöl Ü., Sagırkaya Z., Sarandöl A., Yurtkuran M. (2004). Romatoid artritli hastalarda anksiyete ve depresyon. Romatizma, 19:7-13.

İnan G. (2009) Romatizmal hastalıklar ve yasam kalitesi. Saghklı Yasam Tarıı Dergisi, Tanıtum Sayıs1:8-15.

Solak Ö., Dündar Ü., Demirdal ÜS., Fidan F., Gökce IY., Ünlü M. (2009). Romatoid artrit hastalarının pittsburgh uyku kalite indeksi ile degerlendirilmesi. Turk J Phys Med Rehab, 55:107110.

Buysse DJ., Reynolds C.F, Monk TH. (1989). The Pittsburgh sleep quality index: A new instrument for psychiatric practice and research. Psychiatry Res, 28:193-213.

Agargün M.Y., Kara H., Anlar O. (1996). Pittsburgh uyku kalitesi indeksinin gecerlik ve güvenirligi. Türk Psikiyatri Derg, 7:107-115.

Kücükdeveci A.A., McKenna S.P., Kutlay S., Gürsel Y., Whalley D., Arasil T. (2000). The development and psychometric assessment of the Turkish version of the Nottingham Health Profile. Int J Rehabil Res, 23:31-38.

Günaydın R., Karatepe A.G., Demirhan A., Koc A., Kaya T. (2009). Romatoid artritli hastalarda yorgunlugun yasam kalitesi üzerine etkisi. Turkiye Klinikleri J Med Sci, 29:911-916.

Cakırbay H., Bilici M., Kavakcı O., Cebi A., Güler M., Tan U. (2004). Sleep quality and immune functions in rheumatoid arthritis patients with and without major depression. Int J Neurosci, 114:245-256.

Drewes A.M. (1999). Pain and sleep disturbances with special reference to fibromyalgia and rheumatoid arthritis. Rheumatol, 38:1035-1038.

Bourguignon C., Labyak S.E., Taibi D. (2003). Investigating sleep disturbances in adults with rheumatoid arthritis. Holist Nurs Pract, 17:241-249.

Moldofsky H., Lue F.A., Smythe H.A. (1983). Alpha EEG. Sleep and morning symptoms in rheumatoid arthritis. J Rheumatol, 10:373-379.

Lavie P., Epstein R., Tzischinsky O. (1992). Actigraphic measurements of sleep in rheumatoid arthritis: comparison of patients with low back pain and healthy controls. J Rheumatol,19:362365.

Nicassio P.M., Wallston K.A. (1992). Longitudinal relationships among pain, sleep problems, and depression in rheumatoid arthritis. J Abnorm Psychol, 101:514-520.

Hirsch M., Carlander B., Verge M. (1994). Objective and subjective sleep disturbances in patients with rheumatoid arthritis: a reappraisal. Arthritis Rheum, 37:41-49.

Lavie P., Epstein R., Tzischinsky O. (1992). Actigraphic measurements of sleep in rheumatoid arthritis: comparison of patients with low back pain and healthy controls. $J$ Rheumatol, 19:362365.

Nicassio P.M., Wallston K.A. (1992). Longitudinal relationships among pain, sleep problems, and depression in rheumatoid arthritis. J Abnorm Psychol, 101:514-520.

Kiper S., Sunal N. (2009). Evaluation of sleep quality in rheumatoid arthritis patients. The Medical Journal of Kocatepe, 10:33-39.

Luyster F.S., Chasens E.R., M.Wasko M.C., Dunbar-Jacob L. (2011). Sleep quality and functional disability in patients with rheumatoid arthritis. J Clin Sleep Med, 7:49-55.

Kaya T., Karatepe A.G., Günaydın R., Türkmen G., Özbek G. (2007).Romatoid artritli hastalarda yasam kalitesi: hastalık aktivitesi, fonksiyonel durum ve saglık durumu ile iliskisi. Rheumatism, 22:119-22.

Nunez M., Sanchez A., Nunez E., Casals T., Alegre C., Munoz-Gomez J. (2006). Patients' perceptions of health related quality of life in rheumatoid arthritis and chronic low back pain. Qual Life Res, 15:93-102. 
Çınar Yücel, Ş., Tokem, Y., Korhan, E. A., \& Çalbay, S. (2014). Investigation into sleep and quality of life in patients with rheumatoid arthritis. International Journal of Human Sciences, 11(1), 457-468. doi: 10.14687/ijhs.v11i1.2706

Borman P., Toy G.G., Babaoglu S., Bodur H., Ciliz D., Alli N. (2007). A comparative evaluation of quality of life and life satisfaction in patients with psoriatic and rheumatoid arthritis. Clin Rheumatol, 26:330-334.

Pollard L., Choy E.H., Scott D.L. (2005). The consequences of rheumatoid arthritis: quality of life measures in the individual patient. Clin Exp Rheumatol, 23:43-52.

Aktekin L.A., Eser F., Sivas F., Keskin D., Ergün Ö., Bodur H. (2008). Altmış yas üstü ve altı romatoid artritli hastalarda hastalık aktivitesi ve yaşam kalitesinin karsılastırlması. Turkish Journal of Geriatrics, 11:181-184.

Kücükdeveci A.A., Sahin H., Ataman S., Griffiths B., Tennant A. (2004). Issues in cross-cultural validity: example from the adaptation, reliability, and validity testing of a Turkish version of the Stanford Health Assessment Questionnaire. Arthritis Rheum, 15: 14-19.

SPSS (2006). SPSS for Windows Version 15. SPSS Inc., Chicago, IL.

Akyol AD. (1993). Yasam kalitesinin hemsirelik yönünden önemi. Ege Üniv. HYO Derg, 9:71-75.

Akyol AD. (1993). Yasam kalitesi ve yaklasımları. Ege Üniv. HYO Derg, 9:75-80. 